\title{
Neurophysiological profile of peripheral neuropathy associated with childhood mitochondrial disease
}

Manoj P. Menezes ${ }^{\mathrm{a}, \mathrm{b}}$, Shamima Rahman ${ }^{\mathrm{c}, \mathrm{d}}$, Kaustuv Bhattacharya ${ }^{\mathrm{b}, \mathrm{e}}$, Damian Clark ${ }^{\mathrm{f}}$, John Christodoulou b,e, n , Carolyn Ellaway ${ }^{\text {b,e }}$, Michelle Farrar ${ }^{\text {g,h }}$, Matthew Pitt ${ }^{\text {I, }}$, Hugo Sampaio ${ }^{\text {h }}$, Tyson L. Ware ${ }^{\mathrm{j}}$, Yehani Wedatilake ${ }^{\mathrm{c}, \mathrm{d}}$, David R. Thorburn ${ }^{\mathrm{k}, \mathrm{l}}$, Monique M. Ryan ${ }^{1, \mathrm{~m}}$, Robert Ouvrier $^{\mathrm{a}, \mathrm{b}}$

a Institute for Neuroscience and Muscle Research and T.Y. Nelson Department of Neurology \& Neurosurgery, The Children's Hospital at Westmead, Sydney, Australia

${ }^{\mathrm{b}}$ Discipline of Paediatrics and Child Health, The Children's Hospital at Westmead Clinical School, The University of Sydney, Sydney, Australia

${ }^{\mathrm{c}}$ Mitochondrial Research Group, Genetics and Genomic Medicine, UCL Institute of Child Health, London, UK

${ }^{\mathrm{d}}$ Metabolic Unit, Great Ormond Street Hospital, London, UK

${ }^{\mathrm{e}}$ Western Sydney Genetics Program, Children's Hospital at Westmead, Sydney, Australia

${ }^{\mathrm{f}}$ Department of Neurology, Women's and Children's Hospital, North Adelaide, Australia

${ }^{\mathrm{g}}$ Discipline of Paediatrics, School of Women's and Children's Health, UNSW Medicine, The University of New South Wales, Sydney, Australia

h Department of Neurology, Sydney Children's Hospital, Sydney, Australia

I Department of Clinical Neurophysiology, Great Ormond Street Hospital, London, UK

${ }^{\mathrm{j}}$ Department Paediatrics, Royal Hobart Hospital, Hobart, Australia

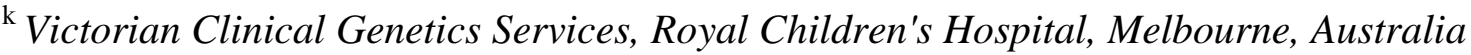

${ }^{1}$ Murdoch Childrens Research Institute, Melbourne, Victoria \& Department of Paediatrics, University of Melbourne, Melbourne, Australia

${ }^{\mathrm{m}}$ Children's Neurosciences Centre, The Royal Children's Hospital, Melbourne, Australia 
n (Present address) Victorian Clinical Genetics Services, Royal Children's Hospital,

Melbourne, Australia \& Murdoch Childrens Research Institute, Melbourne, Victoria \& Department of Paediatrics, University of Melbourne, Melbourne, Australia

Correspondence to:

Manoj Menezes, Institute for Neuroscience and Muscle Research, The Children's Hospital at Westmead, Westmead, NSW, Australia 2145. Tel: 61(2) 98452551. Fax: 61(2) 98453905 Email: manoj.menezes@health.nsw.gov.au

Abstract: 252 words

Title: 99 characters

Words: 2831 words

Tables: 4 Figures: 0 References: 44 


\section{Abstract}

2 Introduction: Peripheral nerve involvement is common in mitochondrial disease but often unrecognised due to the prominent central nervous system features. Identification of the underlying neuropathy may assist syndrome classification, targeted genetic testing and rehabilitative interventions.

Methods: Clinical data and the results of nerve conduction studies were obtained retrospectively from the records of four tertiary children's hospital metabolic disease, neuromuscular or neurophysiology services. Nerve conductions studies were also performed prospectively on children attending a tertiary metabolic disease service. Results were classified and analysed according to the underlying genetic cause.

Results: Nerve conduction studies from 27 children with mitochondrial disease were included in the study (mitochondrial DNA (mtDNA) - 7, POLG - 7, SURF1 - 10, PDHc deficiency - 3). Four children with mtDNA mutations had a normal study while three had mild abnormalities in the form of an axonal sensorimotor neuropathy when not acutely unwell. One child with MELAS had a severe acute axonal motor neuropathy during an acute stroke-like episode that resolved over 12 months. Five children with POLG mutations and disease onset beyond infancy had a sensory ataxic neuropathy with an onset in the second decade of life, while the two infants with $P O L G$ mutations had a demyelinating neuropathy. Seven of the 10 children with SURF1 mutations had a demyelinating neuropathy. All three children with PDHc deficiency had an axonal sensorimotor neuropathy. Unlike CMT, the neuropathy associated with mitochondrial disease was not length-dependent.

Conclusions: This is the largest study to date of peripheral neuropathy in geneticallyclassified childhood mitochondrial disease. Characterising the underlying neuropathy may assist with the diagnosis of the mitochondrial syndrome and should be an integral part of the assessment of children with suspected mitochondrial disease. 
Mitochondrial Neuropathy

26 Key words: mitochondrial disease, childhood, neuropathy, demyelinating, mitochondrial 27 DNA 


\section{Introduction}

Childhood mitochondrial diseases have a heterogeneous phenotype with many different systems being affected including the peripheral nervous system. Around $30 \%$ of children with a mitochondrial disease have an associated peripheral neuropathy (Colomer, et al., 2000), but the neuropathy is often unrecognised due to the overwhelming central nervous system manifestations. Mutations in nuclear genes responsible for mitochondrial dynamics and axonal transport, including $M F N 2$ and GDAP1, are recognised causes of Charcot-MarieTooth disease (CMT) (Niemann, et al., 2005; Züchner, et al., 2004). Recently, mutations in MT-ATP6 and SURF1, genes known to cause Leigh syndrome and other multisystemic mitochondrial diseases, have also been shown to cause phenotypes characterised predominantly by a peripheral neuropathy (Echaniz-Laguna, et al., 2013; Pitceathly, et al., 2012). Identifying the presence of a peripheral neuropathy and defining its characteristics may help with classifying the mitochondrial syndrome and targeted genetic testing (Menezes and Ouvrier, 2012). The associated peripheral neuropathy may be symptomatic and disabling and specific treatment and rehabilitative intervention may be needed.

\section{Methods}

Children with mitochondrial disease and identified mutations who had previously undergone nerve conduction studies were identified from the mitochondrial diseases database at the Murdoch Childrens Research Institute, Melbourne, Australia, the records of the Genetic Metabolic Disorders Clinic at The Children's Hospital at Westmead, Sydney, Australia, the Sydney Children's Hospital Randwick Nerve and Muscle Clinic and the Neurophysiology Department at Great Ormond Street Children's Hospital, London, UK. Nerve conduction studies were also performed prospectively according to a defined protocol (see Supplementary Methods) on children from the Genetic Metabolic Disorders Clinic at The 
1 Children's Hospital at Westmead who had identified mitochondrial mutations and consented

2 to inclusion in the study. Children with pyruvate dehydrogenase complex (PDHc) deficiency

3 were included if there was biochemical confirmation of the PDHc deficiency, even if a

4 genetic mutation had not been identified. The data from both retrospective and prospective

5 groups were combined and classified according to the underlying genetic cause. The results

6 were compared with age-matched normative values (Cai and Zhang, 1997). Because of a lack

7 of published paediatric electrodiagnostic criteria for demyelination in inherited neuropathies,

8 the EFNS/PNS electrodiagnostic criteria for demyelination in chronic inflammatory

9 demyelinating neuropathy were used (Hughes, et al., 2006). These criteria require a $30 \%$

10 reduction of motor conduction velocity below the lower limit of normal in at least one nerve.

11 Both retrospective and prospective studies were approved by the Sydney Children's Hospital

12 Network Ethics Committee (10/56), and the retrospective study at Great Ormond Street Hospital by the National Research Ethics Committee London Bloomsbury, UK.

\section{Results}

Nerve conduction data were available from 27 children from 25 families with a genetically classified mitochondrial disease or biochemically-defined PDHc deficiency. The data were collected over a six-year period (2010-2015). Retrospective nerve conduction studies were available for 20 children and prospective nerve conduction studies were performed on seven children. All nerve conduction studies in the retrospective series were performed because of the clinical suspicion of a neuropathy, except in individual 3, who was investigated because of the known association of a neuropathy with retinitis pigmentosa. One child in the prospective study also had data included from another nerve conduction study performed four years previously. Seven children had mitochondrial genome mutations and 20 had nuclear DNA mutations (POLG-7,SURF1 - 10, PDHc deficiency - 3). All genetic 
1 diagnoses were established after Sanger sequencing of individual nuclear or mitochondrial

2 genes or after testing of a panel of common mitochondrial genome mutations. None of the

3 diagnoses were established by next generation sequencing technologies. All identified

4 mutations have been previously reported as pathogenic except the c.897G>A (p.Met299Ile)

5 variant in $P O L G$ (individual 9 in table 2). The neurophysiological results were categorised by

6 the causative gene (Tables 1-4).

7

\subsection{Mitochondrial DNA mutations}

Neurophysiologic findings in seven children (from six families) with mutations in the mitochondrial genome were evaluated (Table 1). Three had Leigh/NARP (neurogenic muscle weakness, ataxia, and retinitis pigmentosa) syndrome due to the m.8993T $>\mathrm{C}$ mutation in $M T$ ATP6, one had MELAS (mitochondrial myopathy, encephalopathy, lactic acidosis, and stroke-like episodes) due to the m.3243A $>\mathrm{G}$ mutation in MT-TL1 and two individuals had single large mtDNA deletions. This group of children had normal studies or mild abnormalities, usually in the form of an axonal sensorimotor neuropathy.

Of the children with $\boldsymbol{M T}$-ATP6 mutations, two (individuals 1 and 3) had presented in the second year of life with developmental delay. Individual 1 had learning difficulties, choreoathetosis, cerebellar ataxia, hypotonia, areflexia and episodes of acute weakness with illness. His nerve conduction studies, done when not acutely ill, showed an axonal motor neuropathy affecting the lower limbs. Individual 3 had a NARP-like phenotype with retinitis pigmentosa but no clinical or neurophysiological evidence of a neuropathy. Individual 2 presented at 11 years of age with severe brainstem involvement (central hypertension, hypoventilation, eye movement abnormality) following a respiratory infection with 
1 widespread cortical, basal ganglia and brainstem changes on MRI. Her nerve conduction

2 study showed an absent sural SNAP but was otherwise normal.

3

One of the siblings with the m.3243A $>\mathrm{G}$ mutation in MT-TL1 had MELAS (patient 5) while the other was asymptomatic (patient 4). The symptomatic sibling had presented at 10 years of age with frequent headache and had a classical MELAS clinical profile with recurrent stroke-like episodes, multiple cortical infarcts, growth failure and seizures. Nerve conduction tests done when he was admitted with an acute stroke-like episode with acute sensorineural hearing loss, ataxia, bilateral intention tremor and reduced reflexes in the lower limbs showed an axonal predominantly motor neuropathy. The studies were repeated a year later, when he was well, and showed almost complete resolution of neuropathy with only borderline reduction of lower limb motor amplitudes.

Prospective neurophysiological studies were undertaken in two individuals with single large mtDNA deletions. One child had Pearson syndrome with sideroblastic anaemia, renal Fanconi syndrome, growth failure, developmental delay and primary adrenal insufficiency while the other had Kearns-Sayre syndrome with sensorineural hearing loss, complete heart block, renal tubular acidosis, cerebellar ataxia, ptosis and ophthalmoplegia. Neither had neurophysiological evidence of a peripheral neuropathy.

\subsection{Nuclear DNA mutations}

\subsubsection{POLG (Polymerase (DNA Directed), Gamma)}

Seven children with compound heterozygous or homozygous mutations in POLG, a nuclear gene responsible for mtDNA maintenance, were included in this study (Table 2). All the identified mutations have been previously reported as pathogenic except the c.897G>A 
1 (p.Met299Ile) variant in POLG (individual 9). This mutation was seen in conjunction with a

2 recurrent mutation, was in a mutational hotspot and was not found on the Exome Aggregation

3 Consortium (ExAC) database. Two children presented within the first two years of life, one

4 with a Myocerebrohepatopathy Spectrum phenotype and the other with gross motor delay.

5 Both had failure to thrive, lactic acidemia, generalised hypotonia and areflexia. The other five

6 patients presented between four and 15 years of age, four with focal seizures and stroke-like

7 episodes while patient 12 presented with intestinal pseudo-obstruction. Two patients had liver

8 dysfunction when treated with sodium valproate. Among the later presentations, features of a

9 neuropathy (sensory ataxia, distal weakness and areflexia) were identified between 10 and 17

10 years of age. Two patients also had sural nerve biopsies that showed an axonal neuropathy

11 with loss of large myelinated fibres. Four of the seven patients had died between the ages of 2 weeks and 31 years.

Nerve conduction studies in the two youngest patients showed a demyelinating motor neuropathy. Nerve conduction studies in the older children invariably showed a severe axonal sensory neuropathy, irrespective of the age at which the studies were performed, with three of the older children having additional motor nerve involvement.

\subsubsection{SURF1 (Surfeit 1)}

Eleven nerve conduction studies from 10 children (from nine families; individuals 16 and 23 were siblings) with homozygous or compound heterozygous SURF1 mutations were included in this study (Table 3). Seven of the children described here (patients 16, 17, 18, 19, $20,22,23$ ) were also included in a description of 44 individuals with SURF1 mutations by Wedatilake et al (Wedatilake, et al., 2013). Presentation was between three days and 18 months of age with poor feeding, vomiting and poor weight gain. The associated neuropathy 
1 was usually evident by 18 months of age with gait ataxia and tremor in the upper limbs. Other

2 common features included growth failure, developmental regression, nystagmus and lactic acidemia. Brain MRI showed changes consistent with Leigh syndrome in all except one child who had a normal MRI at one year of age. Reduced or absent cytochrome c oxidase (COX) activity in muscle or cultured fibroblasts was seen in all nine children who had this tested. Nine of the children died between 20 months and seven years of age and one child was alive at 12 years.

Seven children had a demyelinating neuropathy, with four having sensorimotor involvement and three isolated motor involvement. Three studies showed predominantly axonal changes with a mild reduction in motor conduction velocity. Unlike typical forms of CMT, the nerve conduction abnormalities were not length-dependent. Three children had only motor involvement on nerve conduction studies.

\subsubsection{PDHc Deficiency}

Three children with PDHc deficiency were included in this study. They had presented in the first two years of life with hypotonia and global or isolated motor delay. Episodes of lactic acidosis associated with generalised weakness and hypotonia were frequent initially but decreased in frequency with advancing age and dietary therapy. Two children also had intellectual delay while one had choreoathetosis and nystagmus. Brain MRI was characteristic of PDHc deficiency with abnormalities in the basal ganglia, substantia nigra and cerebellar white matter. The study in patient 27 was performed 8 weeks into an episode of acute weakness. The nerve conduction studies showed a patchy axonal, non-length dependent sensorimotor neuropathy (Table 4). Sensory responses were universally absent, even in studies done at a young age. 


\section{Discussion}

Normal mitochondrial function is essential for neuronal growth, function and survival (Sheng, 2014). The genes that affect mitochondrial function may cause peripheral neuropathy by alteration in the mitochondrial dynamics of fusion, fission and axonal transport, or due to abnormalities in energy production. (Cassereau, et al., 2009; Chen, et al., 2003; Hollenbeck and Saxton, 2005; Misko, et al., 2010; Sheng and Cai, 2012; Song, et al., 2009; Vallat, et al., 2008). The neuropathy associated with CMT is usually length-dependent, with weakness starting and being more pronounced distally, and the lower limbs being affected earlier and more severely than the upper limbs. Neurophysiology in CMT often parallels this clinical picture with axonal degeneration (primary in CMT2 and secondary to a demyelinating process in CMT1), as measured by the CMAP and SNAP amplitudes, of greater severity in the lower limbs (Kamholz, et al., 2000; Krajewski, et al., 2000; Scherer, 1999). In contrast, this study shows that the nerve conduction abnormalities in children with mitochondrial disease are generally not length-dependent.

While our study was not designed to measure the absolute frequency of neuropathy in patients with mtDNA and nuclear DNA mutations, peripheral nerve involvement was more common in children with nuclear DNA mutations ( $7 / 7$ children with $P O L G, 10 / 10$ children with SURF1 and 3/3 children with PDHc deficiency) when compared with those with mtDNA mutations (3/7 children). Horga et al. found that in individuals with progressive external ophthalmoplegia, the presence of a peripheral neuropathy had the highest specificity (91\%), negative predictive value (83\%) and positive likelihood ratio (5.87) for the diagnosis of a nuclear DNA defect, as opposed to a mitochondrial gene defect (Horga, et al., 2014). 


\subsection{Mitochondrial DNA mutations}

Peripheral neuropathy was uncommon in those with mtDNA mutations, with affected children having either normal nerve conduction studies or a mild neuropathy when not acutely ill. Out of the nine children in the cohort of adults and children with MELAS described by Kaufmann et al., five had normal nerve conduction studies while another three had only borderline reductions in peroneal CMAP amplitudes (Kaufmann, et al., 2006b). Of the 67 individuals with Leigh and Leigh-like syndrome described by Rahman et al, none of 12 individuals with a mutation involving the mitochondrial genome had an identified peripheral neuropathy, although not all were investigated with nerve conduction studies (Rahman, et al., 1996). In individuals with the NARP phenotype, the presence of a peripheral neuropathy in the first two decades of life is specific to the m.9185T $>$ C mutation (Childs, et al., 2007). Peripheral neuropathy is uncommon with single large mitochondrial deletions and has been described in only a single case report (McDonald, et al., 2002).

\subsection{Nuclear DNA mutations}

\subsection{1. $P O L G$}

In our study, in those who presented beyond infancy, $P O L G$ mutations were associated with an axonal sensory neuropathy with variable motor involvement, with clinical onset in the second decade of life. While a 'sensory ataxic neuropathy' almost universally develops in individuals with late-onset $P O L G$ syndromes, its onset is usually late in the second decade or beyond (Hakonen, et al., 2005; Neeve, et al., 2012; Schulte, et al., 2009), although an earlier onset has occasionally been described (Tzoulis, et al., 2006; Wong, et al., 2008). While hypotonia and areflexia are listed as features of $P O L G$ mutations in the first year of life, there are very few reports of the nerve conduction findings of affected children. Our study included two young children with $P O L G$ mutations and demyelinating motor 
1 neuropathies. In a cohort of eight children with Alpers syndrome and POLG mutations,

2 Ferrari et al. reported two infants with neurophysiological or biopsy evidence of a demyelinating neuropathy (Ferrari, et al., 2005). Recessive mutations in PEO1, the gene encoding mitochondrial Twinkle helicase, present with a similar phenotypic spectrum to $P O L G$ and are also associated with an early-onset sensory neuropathy (Lönnqvist, et al., 2009).

\subsubsection{SURF1}

SURF1 mutations were predominantly associated with a demyelinating neuropathy. In the report by Wedatilake et al, 13 of 16 individuals who had undergone nerve conduction studies had a neuropathy, which was demyelinating in seven cases. Echaniz-Laguna and colleagues have reported two families presenting with SURF1 mutations with a childhoodonset demyelinating sensorimotor neuropathy, initially diagnosed as CMT (Echaniz-Laguna, et al., 2013). MNGIE (mitochondrial neurogastrointestinal encephalomyopathy) due to mutations in the TYMP gene is also reported to be associated with a childhood-onset demyelinating neuropathy (Garone, et al., 2011; Hirano, et al., 2004).

\subsubsection{PDHc deficiency}

PDHc deficiency was characterised by axonal sensorimotor neuropathy. Previously published case reports and a single case series of children with PDHc deficiency and neuropathy describe a predominantly axonal neuropathy with significantly reduced CMAP amplitudes and mildly reduced nerve conduction velocities (Bonne, et al., 1993; Chabrol, et al., 1994; Di Rocco, et al., 2000; Federico, et al., 1990; Koga, et al., 2012; Marsac, et al., 1997). In these reports, the axonal neuropathy was recognised in both those investigated prior to institution of treatment with thiamine as well as those on treatment. Only a single 
1 individual had a more significant reduction of median motor conduction velocity, which

2 improved from $19.8 \mathrm{~m} / \mathrm{s}$ to $37.9 \mathrm{~m} / \mathrm{s}$ following treatment with thiamine (Di Rocco, et al.,

2000). Long term treatment with dicholoroacetate, used to treat lactic acidosis in children with PDHc deficiency, has been shown to cause a reversible axonal neuropathy and animal studies have shown that thiamine may mitigate the severity of this neuropathy (Berendzen, et al., 2006; Kaufmann, et al., 2006a; Stacpoole, et al., 1990).

\subsection{Acute neuropathy with mitochondrial disease}

An acute neuropathy has only rarely been described in mitochondrial disease (Coker, 1993; Hara, et al., 1994; Stickler, et al., 2003). In our study, one child with MELAS developed an acute axonal neuropathy during an acute stroke-like episode. Acute reversible axonal dysfunction related to energy failure in peripheral nerves has been shown to occur during stroke-like episodes in MELAS (Farrar, et al., 2010). It is possible that an acute neuropathy accompanies stroke-like episodes in MELAS but is under-recognised due to the prominent central nervous system features. In our study, two children with PDHc deficiency had evidence of an axonal sensorimotor neuropathy on studies performed when they were not acutely ill. Debray et al. described 13 individuals with PDHc deficiency and acute weakness. Of the seven who had undergone nerve conduction studies, five had evidence of a peripheral neuropathy (Debray, et al., 2006). The lack of nerve conduction studies before the onset of weakness or after recovery makes it difficult to determine if the neuropathy was chronic or if an acute metabolic neuropathy or worsening of a pre-existing neuropathy was responsible for the acute weakness.

The combination of retrospective and prospective data is a limitation of this study, with the retrospectively collected studies having been performed with different protocols. As 
1 the retrospective group included only those known to have had nerve conduction studies on

2 the clinical suspicion of a neuropathy, this study was not designed to characterise the

3 frequency of peripheral neuropathy in different mitochondrial diseases. It is, however, the

$4 \quad$ largest study to date of peripheral neuropathy in genetically- classified childhood

5 mitochondrial disease and provides valuable data on the characteristics of the peripheral

6 neuropathy associated with different mitochondrial diseases.

\section{3. Conclusion}

9

We have characterised the neuropathy associated with the major genetic classes of childhood mitochondrial disease. Our findings may help to classify the mitochondrial syndrome and direct genetic testing. Detailed phenotyping including the characteristics of the associated neuropathy may also be useful in confirming the pathogenicity of variants found in whole exome/genome sequencing. In contrast to CMT, the neuropathy of paediatric mitochondrial disease is not length-dependent. Nerve conduction studies should be an integral component of the diagnostic evaluation of suspected childhood mitochondrial disease.

\section{Funding sources}

This work was supported by a National Health and Medical Research Council of Australia (NH\&MRC) postgraduate scholarship. 
Table 1: Neurophysiological profile of children with mitochondrial genome mutations $(n=7)$

\begin{tabular}{|c|c|c|c|c|c|c|c|c|c|}
\hline $\begin{array}{l}\text { Pt./ } \\
\text { Sex }\end{array}$ & Syndrome & Mutation & $\begin{array}{c}\text { Age at } \\
\text { presentation }\end{array}$ & $\begin{array}{c}\text { Signs } \\
\text { suggestive of } \\
\text { neuropathy }\end{array}$ & $\begin{array}{l}\text { Age at NCS, } \\
\text { Retrospective } \\
\text { /Prospective }\end{array}$ & $\begin{array}{l}\text { Upper limb } \\
\text { motor } \\
\text { [CMAP(mV)/ } \\
\mathrm{CV}(\mathrm{m} / \mathrm{s})]\end{array}$ & $\begin{array}{l}\text { Lower limb } \\
\text { motor } \\
\text { [CMAP(mV)/ } \\
\mathrm{CV}(\mathrm{m} / \mathrm{s})]\end{array}$ & $\begin{array}{c}\text { Upper limb } \\
\text { sensory } \\
{[\mu \mathrm{V}]}\end{array}$ & $\begin{array}{c}\text { Lower limb } \\
\text { sensory } \\
(\mu \mathrm{V})\end{array}$ \\
\hline $1 / M$ & Leigh & $\begin{array}{l}\text { MT-ATP6 } \\
\text { m.8993T >C }\end{array}$ & $2 y$ & $\begin{array}{l}\text { hypotonia, } \\
\text { ataxia, } \\
\text { generalised } \\
\text { weakness } \\
\text { (acute with } \\
\text { illness) }\end{array}$ & $5 y / R$ & (M) $14.2 / 54$ & $\begin{array}{l}\text { (P) } 1.7 / 46 \\
\text { (T) } 1.4 / 38\end{array}$ & (M) 25 & (S) 38 \\
\hline $2 / \mathrm{F}$ & Leigh & $\begin{array}{l}\text { MT-ATP6 } \\
\text { m.8993T>C }\end{array}$ & $12 y$ & - & $12 y / P$ & (M) 4.9/52 & (P) $3.5 / 43$ & (M) 16 & (S) NR \\
\hline $3 / F$ & NARP & $\begin{array}{l}\text { MT-ATP6 } \\
\text { m.8993T >C }\end{array}$ & $16 y$ & - & $16 y / R$ & (M) NA/46 & (P) NA/46 & (M) 15 & (S) 10 \\
\hline $4 / M$ & MELAS & $\begin{array}{l}M T-T L 1 \\
\mathrm{~m} .3243 \mathrm{~A}>\mathrm{G}\end{array}$ & $9 y$ & - & $11 y / P$ & $\begin{array}{l}\text { (M) } 9 / 54 \\
\text { (U) } 9.6 / 60\end{array}$ & $\begin{array}{l}\text { (P) } 5.3 / 46 \\
\text { (T) } 17.3 / 49\end{array}$ & $\begin{array}{l}\text { (M) } 26 \\
\text { (U) } 20\end{array}$ & (S) 5 \\
\hline \multirow[t]{2}{*}{$5 / M$} & \multirow[t]{2}{*}{ MELAS } & \multirow{2}{*}{$\begin{array}{l}M T-T L 1 \\
\mathrm{~m} .3243 \mathrm{~A}>\mathrm{G}\end{array}$} & \multirow[t]{2}{*}{$10 y$} & \multirow{2}{*}{$\begin{array}{c}\text { ataxia, } \\
\text { areflexia } \\
\text { (during acute } \\
\text { episode) }\end{array}$} & $12 y / P$ & $\begin{array}{l}\text { (M) } 2.7 / 56 \\
\text { (U) NR/NR }\end{array}$ & $\begin{array}{l}\text { (P) NR/NR } \\
\text { (T) NR/NR }\end{array}$ & $\begin{array}{l}\text { (M) } 23 \\
\text { (U) } 15\end{array}$ & (S) NR \\
\hline & & & & & $13 y / P$ & $\begin{array}{l}\text { (M) } 10.3 / 59 \\
\text { (U) } 9.5 / 59\end{array}$ & $\begin{array}{l}\text { (P) } 2.0 / 47 \\
\text { (T) } 8.7 / 51\end{array}$ & $\begin{array}{l}\text { (M) } 26 \\
\text { (U) } 12\end{array}$ & (S) NR \\
\hline $6 / M$ & Pearson & $\begin{array}{l}\text { single mtDNA } \\
\text { deletion }\end{array}$ & $7 \mathrm{~m}$ & - & $4 y / P$ & $\begin{array}{l}\text { (M) } 7.6 / 45 \\
\text { (U) } 6.7 / 62\end{array}$ & (T) 9.9/48 & (M) 35 & (S) 9 \\
\hline $7 / M$ & $\begin{array}{l}\text { Kearns- } \\
\text { Sayre }\end{array}$ & $\begin{array}{l}\text { single mtDNA } \\
\text { deletion }\end{array}$ & $11 y$ & - & $15 y / P$ & $\begin{array}{l}\text { (M) } 14.8 / 68 \\
\text { (U) } 13.9 / 65\end{array}$ & $\begin{array}{l}\text { (P) } 5.1 / 58 \\
\text { (T) } 23.2 / 58\end{array}$ & $\begin{array}{l}\text { (M) } 10 \\
\text { (U) } 11\end{array}$ & (S) 16 \\
\hline
\end{tabular}

Abnormal results (<2SD) in bold. Reference values from Cai et al.(Cai and Zhang, 1997). Hz - homozygous, w-weeks, m- months, y-years, R - retrospective, $\mathrm{P}$ - prospective, CMAP - compound muscle action potential, CV - conduction velocity, SNAP - sensory nerve action potential, 
M - median, U - ulnar, P - peroneal, T - tibial, S - sural, Sp - superficial peroneal, Mp - medial plantar, NR - not recordable, NA - not available, sup - superficial, empty box indicates this nerve was not studied 
Table 2: Neurophysiological profile of children with $P O L G$ mutations $(n=7)$

\begin{tabular}{|c|c|c|c|c|c|c|c|c|}
\hline $\begin{array}{l}\text { Pt./ } \\
\text { Sex }\end{array}$ & Mutation & $\begin{array}{l}\text { Age at } \\
\text { presentation }\end{array}$ & $\begin{array}{l}\text { Signs suggestive of } \\
\text { neuropathy }\end{array}$ & $\begin{array}{l}\text { Age at NCS, } \\
\text { Retrospective/ } \\
\text { Prospective }\end{array}$ & $\begin{array}{l}\text { Upper limb } \\
\quad \text { motor } \\
{[\mathrm{CMAP}(\mathrm{mV}) /} \\
\mathrm{CV}(\mathrm{m} / \mathrm{s})]\end{array}$ & $\begin{array}{l}\text { Lower limb } \\
\quad \text { motor } \\
{[\mathrm{CMAP}(\mathrm{mV}) /} \\
\mathrm{CV}(\mathrm{m} / \mathrm{s})]\end{array}$ & $\begin{array}{l}\text { Upper limb } \\
\text { sensory } \\
{[\mu \mathrm{V}]}\end{array}$ & $\begin{array}{l}\text { Lower limb } \\
\text { sensory } \\
(\mu \mathrm{V})\end{array}$ \\
\hline $8 / \mathrm{M}$ & $\begin{array}{l}\text { c. } 1399 \mathrm{G}>\mathrm{A} / \\
\text { c. } 695 \mathrm{G}>\mathrm{A}\end{array}$ & $2 w$ & hypotonia, areflexia & $2 w / R$ & (U) NA/8 & (T) NA/10 & & \\
\hline $9 / M$ & $\begin{array}{c}\text { c. } 2551 \mathrm{~A}>\mathrm{G} / \\
\text { c. } 897 \mathrm{G}>\mathrm{A}\end{array}$ & $7 \mathrm{~m}$ & hypotonia, areflexia & $1 y / R$ & (M) 4.5/16.7 & $\begin{array}{l}\text { (P) } 1.1 / 25.5 \\
\text { (T) } 1.7 / 25.7\end{array}$ & (M) NR & (S) NR \\
\hline $10 / \mathrm{F}$ & $\begin{array}{c}\mathrm{Hz} \\
\text { c. } 911 \mathrm{~T}>\mathrm{G}\end{array}$ & $4 y$ & $\begin{array}{l}\text { foot drop, ataxia, } \\
\text { distal lower limb } \\
\text { weakness, distal lower } \\
\text { limb sensory loss, } \\
\text { areflexia }\end{array}$ & $10 y / R$ & (M) $8.8 / 56$ & $\begin{array}{l}\text { (P) } 4.0 / 49 \\
\text { (T) } 9.0 / 47\end{array}$ & $\begin{array}{l}\text { (M) NR } \\
\text { (U) NR }\end{array}$ & (S) NR \\
\hline \multirow{2}{*}{$11 / \mathrm{F}$} & \multirow{2}{*}{$\begin{array}{c}\mathrm{Hz} \\
\text { c.1399G }>\mathrm{A}\end{array}$} & \multirow{2}{*}{$7 y$} & \multirow{2}{*}{$\begin{array}{l}\text { ataxia, tremor, } \\
\text { areflexia }\end{array}$} & $13 y / R$ & (M) $10.4 / 48$ & (P) $2.7 / 45$ & (M) 20 & $\begin{array}{l}\text { (S) NR } \\
\text { (Sp) NR }\end{array}$ \\
\hline & & & & $16 y / R$ & (U) 6.4/46 & $\begin{array}{l}\text { (P) } 1.8 / 42 \\
\text { (T) } 4.6 / \mathrm{NA}\end{array}$ & (M) 19 & $\begin{array}{l}\text { (S) NR } \\
\text { (Sp) NR }\end{array}$ \\
\hline $12 / \mathrm{M}$ & $\begin{array}{c}\text { c. } 1943 C>G / \\
\text { c. } 926 G>A\end{array}$ & $12 y$ & $\begin{array}{l}\text { pes cavus, foot drop, } \\
\text { ataxia, distal lower } \\
\text { limb weakness, distal } \\
\text { lower limb sensory } \\
\text { loss, areflexia }\end{array}$ & $16 y / R$ & (U) NA/23 & (T) NR/NR & (M) NR & \\
\hline $13 / M$ & $\begin{array}{l}\text { c. } 2551 \mathrm{~A}>\mathrm{G} / \\
\text { c. } 3140 \mathrm{G}>\mathrm{A}\end{array}$ & $17 y$ & $\begin{array}{l}\text { pes cavus, ataxia, } \\
\text { distal lower limb } \\
\text { weakness, areflexia }\end{array}$ & $17 y / R$ & (U) NA/47.8 & (P) NR/NR & $\begin{array}{l}\text { (M) } 6.7 \\
\text { (U) } 6.1\end{array}$ & (S) NR \\
\hline $14 / F$ & $\begin{array}{c}\mathrm{Hz} \\
\text { c. } 1399 \mathrm{G}>\mathrm{A}\end{array}$ & $15 y$ & ataxia, areflexia & $19 y / R$ & $\begin{array}{l}\text { (M) } 14.1 / 46.8 \\
\text { (U) } 6.1 / 49.4\end{array}$ & $\begin{array}{l}\text { (P) } 3.0 / 45 \\
\text { (T) } 2.7 / 39.3\end{array}$ & $\begin{array}{l}\text { (M) NR } \\
\text { (U) NR }\end{array}$ & $\begin{array}{l}\text { (S) NR } \\
\text { (Sp) NR }\end{array}$ \\
\hline
\end{tabular}

Abnormal results (<2SD) in bold. Reference values from Cai et al.(Cai and Zhang, 1997). Hz - homozygous, w-weeks, m- months, y-years, R - retrospective, $\mathrm{P}$ - prospective, CMAP - compound muscle action potential, $\mathrm{CV}$ - conduction velocity, SNAP - sensory nerve action potential, 
M - median, U - ulnar, P - peroneal, T - tibial, S - sural, Sp - superficial peroneal, Mp - medial plantar, NR - not recordable, NA - not available, sup - superficial, empty box indicates this nerve was not studied 
Table 3: Neurophysiological profile of children $S U R F 1$ mutations $(n=10)$

\begin{tabular}{|c|c|c|c|c|c|c|c|c|}
\hline $\begin{array}{l}\text { Pt./ } \\
\text { Sex }\end{array}$ & Mutation & $\begin{array}{c}\text { Age at } \\
\text { presentation }\end{array}$ & $\begin{array}{c}\text { Signs } \\
\text { suggestive of } \\
\text { neuropathy }\end{array}$ & $\begin{array}{l}\text { Age at NCS, } \\
\text { Retrospective } \\
\text { /Prospective }\end{array}$ & $\begin{array}{c}\text { Upper limb } \\
\text { motor } \\
\text { [CMAP(mV)/ } \\
\mathrm{CV}(\mathrm{m} / \mathrm{s})]\end{array}$ & $\begin{array}{c}\text { Lower limb } \\
\text { motor } \\
\text { [CMAP(mV)/ } \\
\mathrm{CV}(\mathrm{m} / \mathrm{s})]\end{array}$ & $\begin{array}{c}\text { Upper limb } \\
\text { sensory } \\
{[\mu \mathrm{V}]}\end{array}$ & $\begin{array}{l}\text { Lower limb } \\
\text { sensory } \\
(\mu \mathrm{V})\end{array}$ \\
\hline $15 / M$ & $\begin{array}{l}\text { c.312_320del10insAT/ } \\
\text { c.532_535delAATA }\end{array}$ & $10 \mathrm{~m}$ & Areflexia & $12 \mathrm{~m} / \mathrm{R}$ & (M) NA/28.4 & (T) NA/22.2 & (M) 17.1 & (S) NR \\
\hline $16 / M$ & $\mathrm{~Hz}$ c. $516-2 \mathrm{~A}>\mathrm{G}$ & $3 d$ & Ataxia, Tremor & $14 \mathrm{~m} / \mathrm{R}$ & & (T) 4.1/21 & & (S) 14 \\
\hline $17 / M$ & $\mathrm{~Hz}$ c. $324-11 T>G$ & $9 m$ & Ataxia & $18 \mathrm{~m} / \mathrm{R}$ & & (T) 1.5/14 & & (S) NR \\
\hline $18 / \mathrm{M}$ & $\begin{array}{l}\mathrm{Hz} \\
\text { c.312_320del10insAT }\end{array}$ & $10 \mathrm{~m}$ & Ataxia, Tremor & $18 \mathrm{~m} / \mathrm{R}$ & & (T) $4.5 / 43$ & & (S) 3 \\
\hline $19 / M$ & $\mathrm{~Hz}$ c. $516-2 \mathrm{~A}>\mathrm{G}$ & $4 m$ & Ataxia & $21 \mathrm{~m} / \mathrm{R}$ & & (T) $5.4 / 35.8$ & & (S) 9.2 \\
\hline \multirow{2}{*}{$20 / \mathrm{F}$} & \multirow{2}{*}{$\mathrm{Hz}$ c. $751 \mathrm{C}>\mathrm{T}$} & \multirow{2}{*}{$9 m$} & \multirow{2}{*}{ Ataxia, Tremor } & $2 y / R$ & & (T) 7.5/22 & (M) NR & \\
\hline & & & & $7 y / R$ & $\begin{array}{l}\text { (M) } 0.6 / \mathrm{NA} \\
\text { (U) } 0.6 / 19.5\end{array}$ & (T) $4 / \mathrm{NA}$ & (M) NR & (S) NR \\
\hline $21 / M$ & $\begin{array}{l}\mathrm{Hz} \\
\text { c.312_320del10insAT }\end{array}$ & $18 \mathrm{~m}$ & $\begin{array}{l}\text { Ataxia, Tremor, } \\
\text { Areflexia }\end{array}$ & $2 y / R$ & (M) 9.4/36.9 & & (M) 6.8 & (S) NR \\
\hline $22 / \mathrm{F}$ & $\begin{array}{l}\text { c. } 240+1 \mathrm{G}>\mathrm{T} \\
\text { c. } 575 \mathrm{G}>\mathrm{A}\end{array}$ & $18 \mathrm{~m}$ & Ataxia, Tremor & $2 y / R$ & (U) 4.7/43 & (T) 5.3/26 & (R) 23 & (Pm) 21 \\
\hline $23 / \mathrm{M}$ & $\mathrm{Hz}$ c. $516-2 \mathrm{~A}>\mathrm{G}$ & 10 & NA & $4 y / R$ & (U) $4.9 / \mathbf{2 8}$ & $\begin{array}{l}\text { (P) } 3.5 / 28 \\
\text { (T) } 3.9 / 18\end{array}$ & (R) 24 & (S) NR \\
\hline $24 / F$ & Hz c.792_793delAG & $2 y$ & $\begin{array}{l}\text { Ataxia, Tremor, } \\
\text { Areflexia }\end{array}$ & $5 y / R$ & (M) 5.6/31.9 & (P) $1.4 / 31.3$ & $\begin{array}{l}\text { (M) } 6 \\
\text { (U) } 7.6\end{array}$ & \\
\hline
\end{tabular}


Abnormal results (<2SD) in bold. Reference values from Cai et al.(Cai and Zhang, 1997). Hz - homozygous, w-weeks, m- months, y-years, R - retrospective, $\mathrm{P}$ - prospective, CMAP - compound muscle action potential, CV - conduction velocity, SNAP - sensory nerve action potential, $\mathrm{M}$ - median, U - ulnar, P - peroneal, T - tibial, S - sural, Sp - superficial peroneal, Mp - medial plantar, NR - not recordable, NA - not available, sup - superficial, empty box indicates this nerve was not studied 
Table 4: Neurophysiological profile of children with PDHc deficiency (n=3)

\begin{tabular}{|c|c|c|c|c|c|c|c|c|}
\hline Pt./Sex & Mutation & $\begin{array}{c}\text { Age at } \\
\text { presentation }\end{array}$ & $\begin{array}{c}\text { Signs } \\
\text { suggestive of } \\
\text { neuropathy }\end{array}$ & $\begin{array}{l}\text { Age at NCS, } \\
\text { Retrospective } \\
\text { /Prospective }\end{array}$ & $\begin{array}{l}\text { Upper limb } \\
\text { motor } \\
\text { [CMAP(mV)/ } \\
\text { CV(m/s)] }\end{array}$ & $\begin{array}{l}\text { Lower limb } \\
\text { motor } \\
\text { [CMAP }(\mathrm{mV}) / \\
\mathrm{CV}(\mathrm{m} / \mathrm{s})]\end{array}$ & $\begin{array}{c}\text { Upper limb } \\
\text { sensory } \\
{[\mu \mathrm{V}]}\end{array}$ & $\begin{array}{c}\text { Lower limb } \\
\text { sensory } \\
(\mu \mathrm{V})\end{array}$ \\
\hline \multirow{3}{*}{$25 / \mathrm{M}$} & \multirow{3}{*}{$\begin{array}{l}\text { PDHA1 } \\
\text { c. } 787 \mathrm{C}>\mathrm{G}\end{array}$} & \multirow{3}{*}{$11 \mathrm{~m}$} & \multirow{3}{*}{$\begin{array}{l}\text { episodic } \\
\text { acute } \\
\text { weakness, } \\
\text { areflexia }\end{array}$} & $1 \mathrm{yr} / \mathrm{R}$ & $\begin{array}{l}\text { (M) } 3.7 / 39 \\
\text { (U) } 4.0 / 52\end{array}$ & $\begin{array}{l}\text { (P) } 2.1 / 52 \\
\text { (T) } 3.9 / 42\end{array}$ & $\begin{array}{l}\text { (M) NR } \\
\text { (U) NR }\end{array}$ & (S) NR \\
\hline & & & & $5 y / P$ & $\begin{array}{l}\text { (M) } 4.8 / 52 \\
\text { (U) } 2.7 / 58\end{array}$ & $\begin{array}{l}\text { (P) } 1.6 / 52 \\
\text { (T) } 4.9 / 47\end{array}$ & (U) NR & (S) NR \\
\hline & & & & $6 y / P$ & $\begin{array}{l}\text { (M) } 6.9 / 50 \\
\text { (U) } 3.8 / 55\end{array}$ & $\begin{array}{l}\text { (P) } 1.9 / 47 \\
\text { (T) } 2.5 / 37\end{array}$ & (M) NR & (S) NR \\
\hline $26 / \mathrm{M}$ & NT & $5 m$ & - & $7 y / P$ & $\begin{array}{l}\text { (M) } 4.9 / 43 \\
\text { (U) } 5.4 / 47\end{array}$ & $\begin{array}{l}\text { (P) } 1.9 / 35 \\
\text { (T) } 4.4 / 35\end{array}$ & $\begin{array}{l}\text { (M) NR } \\
\text { (U) NR }\end{array}$ & (S) NR \\
\hline $27 / M$ & NT & $3 y$ & $\begin{array}{l}\text { distal } \\
\text { weakness, } \\
\text { areflexia }\end{array}$ & $\begin{array}{l}11 y / R \\
\text { ( } 8 \text { weeks into } \\
\text { acute } \\
\text { episode) }\end{array}$ & $\begin{array}{l}\text { (M) } 0.7 / 57 \\
\text { (U) } 5.5 / 51\end{array}$ & $\begin{array}{l}\text { (P) NR/NR } \\
\text { (T) } 0.2 / 36\end{array}$ & (M) NR & (S) NR \\
\hline
\end{tabular}

Abnormal results (<2SD) in bold. Reference values from Cai et al.(Cai and Zhang, 1997). Hz - homozygous, w-weeks, m- months, y-years, R - retrospective, $\mathrm{P}$ - prospective, CMAP - compound muscle action potential, CV - conduction velocity, SNAP - sensory nerve action potential, $\mathrm{M}$ - median, U - ulnar, P - peroneal, T - tibial, $\mathrm{S}$ - sural, $\mathrm{Sp}$ - superficial peroneal, Mp - medial plantar, NR - not recordable, NA - not available, sup - superficial, empty box indicates this nerve was not studied 


\section{References}

Berendzen K, Theriaque DW, Shuster J, Stacpoole PW (2006). Therapeutic potential of dichloroacetate for pyruvate dehydrogenase complex deficiency. Mitochondrion 6:126-135. Bonne G, Benelli C, De Meirleir L, Lissens W, Chaussain M, Diry M, Clot JP, Ponsot G, Geoffroy V, Leroux JP, et al. (1993). E1 pyruvate dehydrogenase deficiency in a child with motor neuropathy. Pediatr Res 33:284-288.

Cai F, Zhang J (1997). Study of nerve conduction and late responses in normal Chinese infants, children, and adults. J Child Neurol 12:13-18.

Cassereau J, Chevrollier A, Gueguen N, Malinge MC, Letournel F, Nicolas G, Richard L, Ferre M, Verny C, Dubas F, Procaccio V, Amati-Bonneau P, Bonneau D, Reynier P (2009). Mitochondrial complex I deficiency in GDAP1-related autosomal dominant Charcot-Marie-Tooth disease (CMT2K). Neurogenetics 10:145-150.

Chabrol B, Mancini J, Benelli C, Gire C, Munnich A (1994). Leigh syndrome: pyruvate dehydrogenase defect. A case with peripheral neuropathy. J Child Neurol 9:52-55.

Chen H, Detmer SA, Ewald AJ, Griffin EE, Fraser SE, Chan DC (2003). Mitofusins Mfn1 and Mfn2 coordinately regulate mitochondrial fusion and are essential for embryonic development. J Cell Biol 160:189-200.

Childs AM, Hutchin T, Pysden K, Highet L, Bamford J, Livingston J, Crow YJ (2007). Variable phenotype including Leigh syndrome with a 9185T>C mutation in the MTATP6 gene. Neuropediatrics 38:313-316.

Coker SB (1993). Leigh disease presenting as Guillain-Barre syndrome. Pediatr Neurol 9:61-63. Colomer J, Iturriaga C, Bestue M, Artuch R, Briones P, Montoya J, Vilaseca MA, Pineda M (2000). Aspects of neuropathy in mitochondrial diseases. Rev Neurol 30:1117-1121.

Debray FG, Lambert M, Vanasse M, Decarie JC, Cameron J, Levandovskiy V, Robinson BH, Mitchell GA (2006). Intermittent peripheral weakness as the presenting feature of pyruvate dehydrogenase deficiency. Eur J Pediatr 165:462-466.

Di Rocco M, Doria Lamba L, Minniti G, Caruso U, Naito E (2000). Outcome of thiamine treatment in a child with Leigh disease due to thiamine-responsive pyruvate dehydrogenase deficiency. Eur J Paediatr Neurol 4:115-117.

Echaniz-Laguna A, Ghezzi D, Chassagne M, Mayencon M, Padet S, Melchionda L, Rouvet I, Lannes B, Bozon D, Latour P, Zeviani M, Mousson de Camaret B (2013). SURF1 deficiency causes demyelinating Charcot-Marie-Tooth disease. Neurology 81:1523-1530.

Farrar MA, Lin CS, Krishnan AV, Park SB, Andrews PI, Kiernan MC (2010). Acute, reversible axonal energy failure during stroke-like episodes in MELAS. Pediatrics 126:e734-739.

Federico A, Dotti MT, Fabrizi GM, Palmeri S, Massimo L, Robinson BH, Malandrini A, Guazzi GC (1990). Congenital lactic acidosis due to a defect of pyruvate dehydrogenase complex (E1). Clinical, biochemical, nerve biopsy study and effect of therapy. Eur Neurol 30:123-127.

Ferrari G, Lamantea E, Donati A, Filosto M, Briem E, Carrara F, Parini R, Simonati A, Santer R, Zeviani $M(2005)$. Infantile hepatocerebral syndromes associated with mutations in the mitochondrial DNA polymerase- $\gamma$ A. Brain 128:723-731.

Garone C, Tadesse S, Hirano M (2011). Clinical and genetic spectrum of mitochondrial neurogastrointestinal encephalomyopathy. Brain 134:3326-3332.

Hakonen AH, Heiskanen S, Juvonen V, Lappalainen I, Luoma PT, Rantamaki M, Goethem GV, Lofgren A, Hackman P, Paetau A, Kaakkola S, Majamaa K, Varilo T, Udd B, Kaariainen H, Bindoff LA, Suomalainen A (2005). Mitochondrial DNA polymerase W748S mutation: a common cause of autosomal recessive ataxia with ancient European origin. Am J Hum Genet 77:430-441.

Hara H, Wakayama Y, Kouno Y, Yamada H, Tanaka M, Ozawa T (1994). Acute peripheral neuropathy, rhabdomyolysis, and severe lactic acidosis associated with $3243 \mathrm{~A}$ to $\mathrm{G}$ mitochondrial DNA mutation. J Neurol Neurosurg Psychiatry 57:1545-1546. 
Hirano M, Nishigaki Y, Marti R (2004). Mitochondrial neurogastrointestinal encephalomyopathy (MNGIE): a disease of two genomes. Neurologist 10:8-17.

Hollenbeck PJ, Saxton WM (2005). The axonal transport of mitochondria. J Cell Sci 118:5411-5419. Horga A, Pitceathly RD, Blake JC, Woodward CE, Zapater P, Fratter C, Mudanohwo EE, Plant GT, Houlden H, Sweeney MG, Hanna MG, Reilly MM (2014). Peripheral neuropathy predicts nuclear gene defect in patients with mitochondrial ophthalmoplegia. Brain 137(Pt 12):3200-3212.

Hughes RA, Bouche P, Cornblath DR, Evers E, Hadden RD, Hahn A, Illa I, Koski CL, Leger JM, NobileOrazio E, Pollard J, Sommer C, Van den Bergh P, van Doorn PA, van Schaik IN (2006). European Federation of Neurological Societies/Peripheral Nerve Society guideline on management of chronic inflammatory demyelinating polyradiculoneuropathy: report of a joint task force of the European Federation of Neurological Societies and the Peripheral Nerve Society. Eur J Neurol 13:326-332. Kamholz J, Menichella D, Jani A, Garbern J, Lewis RA, Krajewski KM, Lilien J, Scherer SS, Shy ME (2000). Charcot-Marie-Tooth disease type 1: molecular pathogenesis to gene therapy. Brain 123 ( Pt 2):222-233.

Kaufmann P, Engelstad K, Wei Y, Jhung S, Sano MC, Shungu DC, Millar WS, Hong X, Gooch CL, Mao X, Pascual JM, Hirano M, Stacpoole PW, DiMauro S, De Vivo DC (2006a). Dichloroacetate causes toxic neuropathy in MELAS: a randomized, controlled clinical trial. Neurology 66:324-330.

Kaufmann P, Pascual JM, Anziska Y, Gooch CL, Engelstad K, Jhung S, DiMauro S, De Vivo DC (2006b). Nerve Conduction Abnormalities in Patients With MELAS and the A3243G Mutation. Arch Neurol 63:746-748.

Koga Y, Povalko N, Katayama K, Kakimoto N, Matsuishi T, Naito E, Tanaka M (2012). Beneficial effect of pyruvate therapy on Leigh syndrome due to a novel mutation in PDH E1alpha gene. Brain Dev 34:87-91.

Krajewski KM, Lewis RA, Fuerst DR, Turansky C, Hinderer SR, Garbern J, Kamholz J, Shy ME (2000). Neurological dysfunction and axonal degeneration in Charcot-Marie-Tooth disease type 1A. Brain 123 ( Pt 7):1516-1527.

Lönnqvist T, Paetau A, Valanne L, Pihko H (2009). Recessive twinkle mutations cause severe epileptic encephalopathy. Brain 132:1553-1562.

Marsac C, Benelli C, Desguerre I, Diry M, Fouque F, De Meirleir L, Ponsot G, Seneca S, Poggi F, Saudubray JM, Zabot MT, Fontan D, Lissens W (1997). Biochemical and genetic studies of four patients with pyruvate dehydrogenase E1 alpha deficiency. Hum Genet 99:785-792.

McDonald DG, McMenamin JB, Farrell MA, Droogan O, Green AJ (2002). Familial childhood onset neuropathy and cirrhosis with the 4977bp mitochondrial DNA deletion. Am J Med Genet 111:191194.

Menezes MP, Ouvrier RA (2012). Peripheral neuropathy associated with mitochondrial disease in children. Dev Med Child Neurol 54:407-414.

Misko A, Jiang S, Wegorzewska I, Milbrandt J, Baloh RH (2010). Mitofusin 2 is necessary for transport of axonal mitochondria and interacts with the Miro/Milton complex. J Neurosci 30:4232-4240.

Neeve VC, Samuels DC, Bindoff LA, van den Bosch B, Van Goethem G, Smeets H, Lombes A, Jardel C, Hirano M, Dimauro S, De Vries M, Smeitink J, Smits BW, de Coo IF, Saft C, Klopstock T, Keiling BC, Czermin B, Abicht A, Lochmuller H, Hudson G, Gorman GG, Turnbull DM, Taylor RW, Holinski-Feder $E$, Chinnery PF, Horvath R (2012). What is influencing the phenotype of the common homozygous polymerase-gamma mutation p.Ala467Thr? Brain 135:3614-3626.

Niemann A, Ruegg M, La Padula V, Schenone A, Suter U (2005). Ganglioside-induced differentiation associated protein 1 is a regulator of the mitochondrial network: new implications for CharcotMarie-Tooth disease. J Cell Biol 170:1067-1078.

Pitceathly RD, Murphy SM, Cottenie E, Chalasani A, Sweeney MG, Woodward C, Mudanohwo EE, Hargreaves I, Heales S, Land J, Holton JL, Houlden H, Blake J, Champion M, Flinter F, Robb SA, Page R, Rose M, Palace J, Crowe C, Longman C, Lunn MP, Rahman S, Reilly MM, Hanna MG (2012). Genetic dysfunction of MT-ATP6 causes axonal Charcot-Marie-Tooth disease. Neurology 79:1145-1154. 
Rahman S, Blok RB, Dahl HH, Danks DM, Kirby DM, Chow CW, Christodoulou J, Thorburn DR (1996). Leigh syndrome: clinical features and biochemical and DNA abnormalities. Ann Neurol 39:343-351. Scherer S (1999). Axonal pathology in demyelinating diseases. Ann Neurol 45:6-7.

Schulte C, Synofzik M, Gasser T, Schols L (2009). Ataxia with ophthalmoplegia or sensory neuropathy is frequently caused by POLG mutations. Neurology 73:898-900.

Sheng ZH (2014). Mitochondrial trafficking and anchoring in neurons: New insight and implications. J Cell Biol 204:1087-1098.

Sheng ZH, Cai Q (2012). Mitochondrial transport in neurons: impact on synaptic homeostasis and neurodegeneration. Nat Rev Neurosci 13:77-93.

Song Z, Ghochani M, McCaffery JM, Frey TG, Chan DC (2009). Mitofusins and OPA1 mediate sequential steps in mitochondrial membrane fusion. Mol Biol Cell 20:3525-3532.

Stacpoole PW, Harwood HJ, Jr., Cameron DF, Curry SH, Samuelson DA, Cornwell PE, Sauberlich HE (1990). Chronic toxicity of dichloroacetate: possible relation to thiamine deficiency in rats. Fundam Appl Toxicol 14:327-337.

Stickler DE, Carney PR, Valenstein ER (2003). Juvenile-onset Leigh syndrome with an acute polyneuropathy at presentation. J Child Neurol 18:574-576.

Tzoulis C, Engelsen BA, Telstad W, Aasly J, Zeviani M, Winterthun S, Ferrari G, Aarseth JH, Bindoff LA (2006). The spectrum of clinical disease caused by the A467T and W748S POLG mutations: a study of 26 cases. Brain 129:1685-1692.

Vallat J-M, Ouvrier RA, Pollard JD, Magdelaine C, Zhu D, Nicholson GAMDP, Grew S, Ryan MM, Funalot B (2008). Histopathological findings in hereditary motor and sensory neuropathy of axonal type with onset in early childhood associated with mitofusin 2 mutations. J Neuropathol Exp Neurol 67:1097-1102.

Wedatilake Y, Brown RM, McFarland R, Yaplito-Lee J, Morris AA, Champion M, Jardine PE, Clarke A, Thorburn DR, Taylor RW, Land JM, Forrest K, Dobbie A, Simmons L, Aasheim ET, Ketteridge D, Hanrahan D, Chakrapani A, Brown GK, Rahman S (2013). SURF1 deficiency: a multi-centre natural history study. Orphanet J Rare Dis 8:96.

Wong LJ, Naviaux RK, Brunetti-Pierri N, Zhang Q, Schmitt ES, Truong C, Milone M, Cohen BH, Wical B, Ganesh J, Basinger AA, Burton BK, Swoboda K, Gilbert DL, Vanderver A, Saneto RP, Maranda B, Arnold G, Abdenur JE, Waters PJ, Copeland WC (2008). Molecular and clinical genetics of mitochondrial diseases due to POLG mutations. Hum Mutat 29:E150-172.

Züchner S, Mersiyanova IV, Muglia M, Bissar-Tadmouri N, Rochelle J, L. DE, Mario Z, Eva N, Alessandra P, Jan S, Yesim P, Oleg E, Peter DJ, Yuji T, Shoij T (2004). Mutations in the mitochondrial GTPase mitofusin 2 cause Charcot-Marie-Tooth neuropathy type 2A. Nat Genet 36:449-451.

\section{SUPPLEMENTARY METHODS}

\section{Nerve conduction tests}

Nerve conduction tests were performed using a Viking ${ }^{\mathrm{TM}}$ On Nicolet $^{\mathrm{TM}}$ EDX

Electrodiagnostic System from CareFusion Nicolet with surface electrodes. Sedation with 
nitrous oxide was used in some children above the age of 12 months. For the motor studies, a supramaximal rectangular pulse direct current stimulus was delivered using a two-prong stimulator, to elicit a compound muscle action potential (CMAP). The median nerve was stimulated at the wrist and elbow and the CMAP was recorded over the bulk of the abductor pollicis brevis (APB) muscle. The ulnar nerve was stimulated over the wrist and behind the elbow and the CMAP was recorded over the bulk of the abductor digiti minimi (ADM) muscle. The common peroneal nerve was stimulated over the ankle and knee and the CMAP was recorded over the bulk of the extensor digitorum brevis (EDB) muscle. The tibial nerve was stimulated over the ankle and behind the knee and the CMAP was recorded over the bulk of the abductor hallucis (AH) muscle. The sweep speed and sensitivities were $5 \mathrm{~ms} /$ division and $5 \mathrm{mV} /$ division respectively. The duration of the stimulus was $0.1 \mathrm{~ms}$.

The sensory nerve action potential (SNAP) was recorded by an orthodromic technique for the upper limb (median and ulnar) nerves and by an antidromic technique for the lower limb (sural) nerve. For the median nerve, the stimulus was delivered by ring electrodes over the index finger (digital branch of the median nerve) and SNAPs were recorded over the wrist. For the ulnar nerve, the stimulus was delivered by ring electrodes over the little finger (digital branch of the ulnar nerve) and SNAPs were recorded over the wrist. For the sural nerve, the stimulus was delivered above the lateral malleolus, approximately $14 \mathrm{~cm}$ from the proximal recording electrode which was placed on the lateral border of the foot. All sensory potentials were recorded using a recurrent stimulus and with averaging using a supramaximal stimulus. The stimulus duration was $0.1 \mathrm{~ms}$ and the sweep speed and sensitivities were $1 \mathrm{~ms} /$ division and $10 \mu \mathrm{V} /$ division respectively. 
The distal motor latencies, CMAP amplitudes and conduction velocities were recorded using conventional methods. CMAP and SNAP amplitudes were measured from baseline to the negative peak of the action potential. The distal motor latency was calculated from the stimulus artefact to the initial negative deflection from the baseline. Normative data was sourced from Cai et al. (Cai and Zhang, 1997). The neuropathy was designated as demyelinating when the nerve conduction velocity was reduced to $<70 \%$ of the lower limit for that age range (lower limit = mean-2SD). The neuropathy was designated as axonal when there was a reduction in the CMAP amplitude and there was no reduction in the conduction velocity, or the reduction did not satisfy criteria for demyelinating neuropathy. Care was taken when the CMAP amplitude was $<1 \mathrm{mV}$ as it is known that measures of conduction velocity in this setting can be erroneous and appear pseudo-demyelinating due to preferential loss of faster conduction fibres. 